\title{
ZBIÓR FOTOGRAFII W ARCHIWUM DIECEZJI KOSZALIŃSKO-KOLOBRZESKIEJ
}

\begin{abstract}
Streszczenie
Po podpisaniu porozumień granicznych między Polską a Republiką Federalną Niemiec w 1970 r. papież Paweł VI ustanowił stałą organizację kościelną na Pomorzu Zachodnim i ziemi lubuskiej. Powstała wówczas diecezja koszalińsko-kołobrzeska. Archiwum Diecezji Koszalińsko-Kołobrzeskiej (dalej: AAKK) zostało erygowane staraniem biskupa diecezjalnego w 2003 r. Działalność instytucji reguluje zatwierdzony statut i wewnętrzny regulamin. Do archiwum są przekazywane archiwalia z kurii biskupiej, parafii, instytucji i od osób prywatnych. Obecny zasób tworzy dokumentacja aktowa i nieaktowa - fotografie, łącznie 18200 obiektów. Zbiory fotograficzne nie są jeszcze opracowane według obecnie wymaganych standardów archiwalnych. Jak dotąd tworzono podręczne spisy oraz podejmowano próbę identyfikacji osób i wydarzeń przedstawionych na zdjęciach. Mimo nieopracowanego zbioru pojedyncze fotografie są udostępniane na potrzeby lokalnych wystaw czy opracowań naukowych.
\end{abstract}

Słowa kluczowe: Archiwum Diecezji Koszalińsko-Kołobrzeskiej; fotografie; bp Czesław Domin; bp Ignacy Jeż

\section{Wprowadzenie}

Zbiory fotograficzne w Archiwum Diecezji Koszalińsko-Kołobrzeskiej pochodzą z XX i XXI wieku. Ich liczba szacowana jest na ok. 18200 obiektów. Nie są one jeszcze profesjonalnie opracowane i nie mają swoich inwentarzy. Ich katalogowanie znajduje się na etapie wstępnym. Pracownicy archiwum posługują się spisami zdawczo-odbiorczymi lub wstępnymi opracowaniami. Zbiór po-

* Ks. Tadeusz Ceynowa - dr historii Kościoła, adiunkt, Wydział Teologiczny, Uniwersytet Szczeciński, dyrektor Archiwum Diecezji Koszalińsko-Kołobrzeskiej, dyrektor Biblioteki WSD w Koszalinie e-mail: tceynowa@interia.pl https://orcid.org/0000-0002-8105-8823 
dzielony jest na albumy, teczki, koperty i pojedyncze zdjęcia. Nie zawsze możliwe jest ustalenie czasu akcesji do archiwum. Największa liczba zdjęć wchodzi w skład spuścizn, materiałów przekazanych przez parafie i akt personalnych. Jak na razie nie podjęto procesu digitalizacji zbiorów. Mimo początkowego stanu opracowania poszczególne obiekty udostępnia się w pracowni archiwum. Są one wykorzystywane okazjonalnie podczas jubileuszowych wystaw i w publikacjach naukowych. Konferencja zorganizowana przez Ośrodek Archiwów, Bibliotek i Muzeów Kościelnych KUL dała asumpt do pierwszego przedstawienia stanu liczbowego, zachowania i udostępniania zbiorów fotograficznych przez archiwum diecezjalne w Koszalinie. To umożliwi dalsze prace archiwalne nad licznym i bogatym zbiorem, co w przyszłości pozwoli na szersze dotarcie do niego przez naukowców i hobbystów.

\section{Miejsce przechowywania i zasób ${ }^{1}$}

Archiwum Diecezji Koszalińsko-Kołobrzeskiej mieści się w Koszalinie przy ul. Seminaryjnej 2, w części budynku należącego do Wyższego Seminarium Duchownego (dalej: WSD). Nie może się ono poszczycić jeszcze długą historią swojego istnienia.

Tereny obecnej diecezji koszalińsko-kołobrzeskiej przed 1939 r. wchodziły w skład dwóch struktur kościelnych - diecezji berlińskiej i Wolnej Prałatury Pilskiej, utworzonych w 1930 r., po zawarciu rok wcześniej konkordatu przez Stolicę Apostolską z Prusami. Ustalenia koalicji wielkich mocarstw z Teheranu, Jałty i Poczdamu dokonały przesunięcia granic w Europie Środkowej. Straty poniesione przez Polskę na wschodzie zrekompensowano jej terytoriami niemieckimi na wschód od Odry i Nysy Łużyckiej. Pełnomocnictwa otrzymane przez kard. Augusta Hlonda w Watykanie umożliwiły utworzenie tymczasowych administracji apostolskich. Jedna z nich, największa, Administracja Apostolska Kamieńska, Lubuska i Prałatury Pilskiej objęła swym zasięgiem terytorium od Lęborka na Pomorzu po ziemię lubuską. Na podstawie ustaleń poczdamskich ludność niemiecka, w zdecydowanej większości ewangelicka, musiała opuścić terytoria przyznane Polsce. Na jej miejsce przybywała, dobrowolnie lub z nakazu, ludność ze wschodnich rubieży II Rzeczypospolitej, a także dobrowolni migranci z różnych rejonów kraju. Tymczasowość kościelna na terenach zachodnich i północnych

\footnotetext{
${ }^{1} \mathrm{Na}$ temat powstania, funkcjonowania i zasobu archiwum można zapoznać się m.in. w publikacjach: T. Ceynowa, Archiwum Diecezji Koszalińsko-Kołobrzeskiej i jego zasób, w: Archiwa ziem zachodnich i pótnocnych Polski (1945-2005). Tradycja i współczesne wyzwania, red. K. Kozłowski, Szczecin-Warszawa 2007, s. 187-193; tenże, Archiwum Diecezji Koszalińsko-Kołobrzeskiej, w: 40-lecie Diecezji Koszalińsko-Kotobrzeskiej 1972-2012, red. T. Ceynowa, Radom 2012, s. 135147; tenże, Archiwum Diecezji Koszalińsko-Kolobrzeskiej - powstanie i funkcjonowanie, w: Przeszłość Kościoła w archiwach Pomorza Zachodniego, red. T. Ceynowa, Radom 2014, s. 133-144; tenże, Duplikaty w Archiwum Diecezji Koszalińsko-Kołobrzeskiej, w: Nova et vetera. Aktualne problemy archiwów diecezjalnych w Polsce, red. W. Żurek, Lublin 2016, s. 87-99; tenże, Katolickie księgi metrykalne diecezji koszalińsko-kołobrzeskiej, „Archiwa, Biblioteki i Muzea Kościelne” (dalej: ABMK), 113 (2020) s. 49-78; tenże, Księgi metrykalne parafii rzymskokatolickiej w Grzymatowie przechowywane w Archiwum Diecezji Koszalińsko-Kołobrzeskiej, ABMK, 112 (2019) s. 93-111.
} 
była częstym powodem konfliktów między władzą komunistyczną a Kościołem. Wieloletnie starania episkopatu Polski z prymasem Stefanem Wyszyńskim na czele doprowadziły do zakończenia takiego stanu. Papież Paweł VI w 1972 r. erygował na terenach Pomorza Zachodniego i ziemi lubuskiej 3 samodzielne diecezje: gorzowską z siedzibą w Gorzowie, szczecińsko-kamieńską z siedzibą w Szczecinie i koszalińsko-kołobrzeską z siedzibą w Koszalinie ${ }^{2}$. Granice diecezji zmieniały się jeszcze w 1992 i 2004 r.

Mimo starań pierwszego ordynariusza bp. Ignacego Jeża nie udało się ustanowić archiwum diecezjalnego ${ }^{3}$. Dopiero pod koniec lat 90 . XX wieku wydzielono kilka pomieszczeń w budynku WSD w Koszalinie i dzięki pomocy Fundacji Polsko-Niemieckiej zaadaptowano je na poczet przyszłego archiwum diecezjalnego. Podstawowym warunkiem $\mathrm{w}$ umowie $\mathrm{z}$ fundacją było zapewnienie nieskrępowanego dostępu do zachowanych archiwaliów dla badaczy z Niemiec. Ówczesny biskup diecezjalny ${ }^{4}$ zaaprobował ten warunek i erygował Archiwum Diecezji Koszalińsko-Kołobrzeskiej jesienią 2003 r. Instytucja ta kieruje się zatwierdzonymi statutami i regulaminem wewnętrznym. Pierwszoplanowym zadaniem pracowników było przejęcie z parafii zachowanych archiwaliów ${ }^{5}$, wytworzonych przed 1945 r. W czasie tej akcji stwierdzono niejednokrotnie nie najlepszy sposób przechowywania akt katolickich i ewangelickich. Taki stan rzeczy thumaczono niezrozumiałym językiem, w którym wytworzono dokumenty. Po zakończeniu tego etapu dokonano akcesji akt $\mathrm{z}$ kurii biskupiej przekazanych w latach 1972-1973 do Koszalina, a wytworzonych w ordynariacie gorzowskim do 1972 r., dotyczących terytoriów diecezji koszalińsko-kołobrzeskiej ${ }^{6}$. Od 2009 r. pracownicy archiwum kompletują również duplikaty ksiąg metrykalnych od $1945 \mathrm{r}$. i na bieżąco nanoszą w nich zmiany. Zasób archiwum powiększa się również sukcesywnie przez dopływ dokumentacji nieaktowej w postaci fotografii. Niektóre $\mathrm{z}$ nich uzupełniają

${ }^{2}$ Istnieje już bogata literatura na ten temat. Zob. m.in.: L. Bończa-Bystrzycki, Zarys dziejów Kościoła katolickiego na Pomorzu Zachodnim w granicach diecezji koszalińsko-kołobrzeskiej, w: Schematyzm Diecezji Koszalińsko-Kołobrzeskiej, Koszalin 1998, s. 69-87; K. Dullak, Podstawy prawno-organizacyjne Diecezji Koszalińsko-Kołobrzeskiej, Koszalin 1996; Archiwum Diecezji Koszalińsko-Kołobrzeskiej (dalej: ADKK), Prywatne Archiwum biskupa Ignacego Jeża, Teczka „Podział”; T. Ceynowa, Koszalińsko-kotobrzeska diecezja, w: Encyklopedia katolicka t. 9, red. A. Szostek, Lublin 2002, kol. 976-978; Narodziny diecezji szczecińsko-kamieńskiej i koszalińsko-kołobrzeskiej (1945-1975), wstęp, wybór i oprac. K. Kozłowski, Szczecin 2007, s. 95-103; L. Bończa-Bystrzycki, Dzieje Kościoła katolickiego na Pomorzu Zachodnim w granicach diecezji koszalińsko-kołobrzeskiej (X-XX/XXI wiek), Koszalin 2012, s. 545-651.

${ }^{3}$ Zorganizowano wówczas jedno pomieszczenie w wieży konkatedry kołobrzeskiej, dokąd sukcesywnie miały być przekazywane duplikaty ksiąg metrykalnych i inne archiwalia.

${ }^{4}$ Biskup Marian Gołębiewski kierował diecezją koszalińsko-kołobrzeską w latach 1996-2004.

${ }^{5}$ Większość tych akt udało się już opracować. Największe zespoły tworzą parafie katolickie w Skrzatuszu, Wałczu, Jastrowiu, Czaplinku, Zakrzewie, Złotowie i Czarnem. Ewangelickie zbiory dotyczą przede wszystkim metrykaliów parafialnych. Zachowały się również akta z Karlina, Świdwina i Słupska.

${ }^{6}$ Wydano inwentarz tych dokumentów: Inwentarz archiwalny. Materiaty archiwalne przekazane przez Diecezję Gorzowska nowo erygowanej Diecezji Koszalińsko-Kołobrzeskiej z lat 19451972, red. T. Ceynowa, Radom 2014. 
już zdeponowaną dokumentację, inne tworzą nowe kolekcje lub pozostają nierozpoznane. Zasób przekazany do koszalińskiej instytucji ma zapewnione odpowiednie warunki przechowywania w zakresie temperatury i wilgotności. Dokumentacja fotograficzna złożona jest w magazynie na regałach jezdnych wyposażonych w metalowe półki, w pudłach archiwalnych z tektury bezkwasowej ${ }^{7} \mathrm{i}$ kopertach zabezpieczonych w teczkach.

Archiwum w swoich zbiorach ma kilkadziesiąt starodruków i podręczną bibliotekę. Pozyskuje się do niej księgozbiór dotyczący historii Pomorza, ziemi lubuskiej i północnej Wielkopolski. Obecnie skatalogowanych jest 2105 woluminów, czasopisma naukowe oraz periodyki diecezjalne. Aktualnie trwają przygotowania do przejmowania akt z parafii z lat 1945-1972 . Pracownicy archiwum diecezjalnego i Biblioteki WSD w Koszalinie redagują „,Rocznik Diecezji Koszalińsko-Kołobrzeskiej” (od 2014 r.) oraz „Koszalińsko-Kołobrzeskie Wiadomości Diecezjalne" (kwartalnik od 2016 r.).

\section{Zbiory fotograficzne}

Fotografie gromadzone w Archiwum Diecezji Koszalińsko-Kołobrzeskiej pochodzą z XX i XXI wieku. Im bliżej czasów współczesnych, tym liczba ich wzrasta. Spowodowane jest to rozwojem i możliwościami fotografowania.

Dokumentacja nieaktowa trafia do archiwum historycznego z urzędów kurialnych, w aktach parafialnych, od poszczególnych duchownych diecezji, stowarzyszeń diecezjalnych i w spuściznach po zmarłych biskupach i księżach. Dokumentacja ta ukazuje ich młodość, wcześniejszą działalność poza diecezją oraz posługę duszpasterską na terenie Kościoła lokalnego.

Do najciekawszych zbiorów należy zaliczyć zdjęcia, które zdeponowano w archiwum wraz ze spuściznami aktowymi dotychczasowych biskupów diecezjalnych: I. Jeża ${ }^{9}$, Czesława Domina ${ }^{10}$ i Mariana Gołębiewskiego. Najbogatsze zbiory

${ }^{7}$ Archiwum Diecezji Koszalińsko-Kołobrzeskiej zaopatruje się w teczki i pudła archiwalne w firmie Beskid Plus.

${ }^{8}$ Proces ten rozpocznie się w przyszłym roku, w jubileusz 50-lecia istnienia diecezji.

${ }^{9}$ Bp Ignacy Jeż - urodził się 31 sierpnia 1914 r. w Radomyślu Wielkim. Święcenia kapłańskie przyjął w 1937 r. w katowickiej prokatedrze. Aresztowany przez gestapo 17 sierpnia 1942 r., został wywieziony do obozu koncentracyjnego w Dachau. Po wyzwoleniu obozu sprawował przez rok opiekę duszpasterską nad Polakami w Niemczech. W 1960 r. został biskupem tytularnym Albae Maritime jako sufragan gnieźnieński z przeznaczeniem do pomocy w administracji gorzowskiej. W 1972 r. został mianowany pierwszym ordynariuszem diecezji koszalińsko-kołobrzeskiej. Zorganizował podstawowe struktury diecezjalne, przeprowadził I Synod Diecezjalny i przyjmował papieża Jana Pawła II w 1991 r. Przeszedł w stan spoczynku w 1992 r. Zmarł w Rzymie 16 października 2007 r., w przeddzień otrzymania tytułu kardynała. Został pochowany w krypcie kolegiaty kołobrzeskiej. Zob. T. Ceynowa, Jeż Ignacy, w: Stownik polskich teologów katolickich 2004-2013, t. 10, red. T. Błaszczyk, Warszawa 2019, s. 453-457; tu szczegółowa bibliografia podmiotowa i szczegółowa.

${ }^{10}$ Bp Czesław Domin - urodził się 6 lipca 1929 r. w Michałkowicach. Święcenia kapłańskie otrzymał w 1953 r. Sakrę biskupią przyją 15 sierpnia 1970 r. w katedrze katowickiej. W 1980 r. objął funkcję przewodniczącego Komisji Charytatywnej Konferencji Episkopatu Polski, a w 1990 r. został przewodniczącym Caritas Polska. 1 lutego 1992 r. otrzymał nominację na biskupa koszalińsko-kołobrzeskiego. Zmarł po ciężkiej chorobie 15 marca 1996 r. Pochowany został w przedsionku 
dotyczą osoby i działalności pierwszego ordynariusza ( 5487 zdjęć). Są to przede wszystkim albumy, których zawartość dotyczy okresu katowickiego do 1960 r., następnie gorzowskiego do 1972 r. oraz koszalińskiego do 2007 r. Fachowe opracowanie tego ciekawego zbioru posłuży z całą pewnością jeszcze wielu badaczom. Nie mniej bogate, choć mniej liczne zbiory (2469 zdjęć) wyodrębniono $\mathrm{z}$ dokumentacji po bp. Cz. Dominie. Na uwagę zasługują fotografie nie tylko z czasu katowickiego do 1992 r. i koszalińskiego do 1966 r., lecz także z okresu jego szerokiej działalności na polu charytatywnym w ramach komisji episkopatu. Zbiory obrazujące tylko posługę w diecezji (1614 zdjęć) dotyczą bp. M. Gołębiewskiego.

W archiwum diecezjalnym zdeponowano dokumentacje aktową i nieaktową po pięciu zmarłych kapłanach: ks. infułacie Wiktorze Paneckim ${ }^{11}$ (10 fotografii), ks. kanoniku Bernardzie Mielcarzewiczu ${ }^{12}$ (288 fotografii), ks. kanoniku dr. Romualdzie Kunickim ${ }^{13}$ ( 6 albumów i zdjęcia luzem - 789 fotografii), ks. kanoniku Janie Borzyszkowskim ${ }^{14}$ (1980 fotografii) i ks. dr. Stanisławie Wojnarze ${ }^{15}$ (16 fo-

katedry koszalińskiej. Zob. T. Ceynowa, Domin Czesław, w: Słownik polskich teologów katolickich 1994-2003, t. 9, red. J. Mandziuk, Warszawa 2006, s. 158-159.

${ }^{11}$ Ks. Wiktor Panecki - urodził się 13 grudnia 1915 r. w Przemyślu. Święcenia kapłańskie przyjął 18 czerwca 1939 r. w katedrze lwowskiej. Aktywnie działał w Związku Harcerstwa Polskiego. W 1946 r. wyjechał do administracji apostolskiej w Gorzowie Wielkopolskim. Pełnił funkcję ojca duchownego w Niższym Seminarium Duchownym w Gorzowie Wielkopolskim, a następnie dyrektora w identycznej placówce w Słupsku. Był długoletnim kapelanem słupskich klarysek. Zmarł 21 stycznia 2001 r. w Słupsku i tam został pochowany. Zob. M. Leszczyński, Księża diecezjalni ekspatrianci archidiecezji lwowskiej obrządku tacińskiego. Słownik biograficzny, Warszawa 2020, s. $580-581$.

${ }^{12}$ Ks. Bernard Mielcarzewicz - urodził się 20 sierpnia 1934 r. w Bydgoszczy. Święcenia kapłańskie przyjął 14 lipca 1957 r. w Gdańsku-Oliwie. Pełnił funkcje duszpasterskie m.in. w Międzyrzeczu, Szczecinie, Wierzchucinie, Łęknie, Szczecinku i Turowie. Sprawował urząd kanclerza kurii biskupiej w Koszalinie. Był wykładowcą WSD w Koszalinie. Zmarł w Szczecinku 6 maja 2016 r. Pochowany został na miejscowym cmentarzu. Zob. Archiwum Kurii Biskupiej, Teczka personalna ks. Bernarda Mielcarzewicza.

${ }^{13}$ Ks. Romuald Kunicki - urodził się 21 czerwca 1934 r. w Suwałkach. Święcenia kapłańskie otrzymał 28 maja 1959 r. Posługę kapłańską pełnił m.in. w parafiach: Międzyrzecz, Myślibórz, Szczecin-Pogodno, Gorzów Wielkopolski i Wałcz. W 1976 r. obronił pracę doktorską na Katolickim Uniwersytecie Lubelskim. Był wieloletnim wykładowcą WSD w Gościkowie-Paradyżu, IWKR w Pile i WSD w Koszalinie. Zmarł 3 kwietnia 2017 r. w Wałczu. Pochowany został na miejscowym cmentarzu. Zob. Ks. Romuald Kunicki (1934-2017), oprac. T. Ceynowa, „Koszalińsko-Kołobrzeskie Wiadomości Diecezjalne”, 45 (2017) nr 2, s. 137-138.

${ }^{14}$ Ks. Jan Borzyszkowski, senior - urodził się 24 grudnia 1930 r. w Nakle k. Bytowa. Święcenia kapłańskie przyjął 20 grudnia 1958 r. Posługę kapłańską pełnił m.in. w parafiach: Kołczygłowy, Krosno Odrzańskie, Podwilcze, Gościno, Świdwin i w parafii katedralnej. Był prześladowany przez władze komunistyczne. Pełnił funkcję pierwszego dyrektora diecezjalnej Caritas. Zmarł 25 czerwca 2014 r. w Koszalinie. Zob. R. Marciniak, Borzyszkowski Jan Sylwester, w: Encyklopedia Solidarności, t. 3: Opozycja w PRL 1976-1989, Warszawa 2019, s. 70.

${ }^{15}$ Ks. Stanisław Wojnar - urodził się 10 grudnia 1930 r. w Osieku Jasielskim. Święcenia kapłańskie otrzymał 1 czerwca 1958 r. Początkowo duszpasterzował w diecezji przemyskiej. W 1979 r. przeniósł się do diecezji koszalińsko-kołobrzeskiej. Był wykładowcą WSD w Koszalinie i odpowie- 
tografii). Zachowane zdjęcia przedstawiają zarówno ich sytuacje rodzinne, jak i działalność duszpasterską w parafiach (budowa kurii koszalińskiej, spotkania kolędowe, sprawowanie sakramentów, pielgrzymki parafialne, a nawet pobyt prezydenta USA Roberta Kennedy'ego w Polsce).

Działalność duszpasterską w parafiach przedstawiają zdjęcia znajdujące się $\mathrm{w}$ aktach parafialnych i kronikach $\mathrm{z}$ lat powojennych przekazanych ${ }^{16}$ do archiwum diecezjalnego. Kroniki seminaryjne obrazują zatrzymane w kadrze życie kleryków koszalińskich od początku lat 80. w Paradyżu i od 1984 r. już w Koszalinie, w nowo erygowanej instytucji. Można na nich zaobserwować studentów teologii w różnorakiej ich działalności: jasełka, kabarety, przedstawienia teatralne, wyjazdy, pielgrzymki i posługi lektoratu czy akolitatu.

Bardzo ciekawą grupę stanowią fotografie przedstawiające budynki sakralne i miejsca kultu. Biskup Domin po objęciu diecezji w 1992 r. i zmianie jej granic nosił się z zamiarem wydania schematyzmu diecezjalnego z bogatym materiałem fotograficznym. W wyniku przygotowań do wydania publikacji wykonano 2098 zdjęć; są na nich kościoły parafialne, filialne, miejsca odprawiania Mszy św. oraz przydrożne krzyże. Podczas remontu kurii cały zbiór wraz z negatywami zdeponowano w archiwum. Niestety, choroba i przedwczesna śmierć biskupa uniemożliwiły zrealizowanie przedsięwzięcia. Podobną tematykę prezentują archiwalia przekazane przez wojewódzkiego konserwatora zabytków. Karty inwentarzowe, sporządzane od lat 60., ukazują sakralne budowle o różnej proweniencji (katolickie i poewangelickie) użytkowane obecnie przez Kościół rzymskokatolicki. W skład tego zbioru wchodzą również zdjęcia zabytków ruchomych zarówno eksponowanych obecnie w kościołach, jak i wypożyczonych do muzeów regionalnych. ADKK posiada również bogate zbiory fotograficzne przedstawiające najważniejsze wydarzenia kościelne: peregrynacja w parafiach obrazu Matki Bożej Częstochowskiej, koronacja koronami papieskimi figury Matki Bożej Bolesnej w Skrzatuszu oraz pobyt Jana Pawła II w Koszalinie 1-2 czerwca 1991 r., skąd rozpoczynał IV pielgrzymkę do Polski. W dwóch kartonach przekazano 3744 zdjęcia luzem i w albumach z działalności Parafialnego Oddziału Akcji Katolickiej z parafii katedralnej w Koszalinie.

dzialnym za I synod diecezjalny. W 2002 r. jako emeryt wrócił w swoje rodzinne strony do archidiecezji przemyskiej i zamieszkał w Kańczudze. Zmarł 23 maja 2017 r. w Przeworsku. Pochowany został na cmentarzu w Kańczudze. Zob. Ks. Stanisław Wojnar (1930-2017), oprac. T. Ceynowa, „Koszalińsko-Kołobrzeskie Wiadomości Diecezjalne”, 45 (2017) nr 2, s. 145-146.

${ }^{16}$ Wykonane kopie kronik przekazano do parafii. 


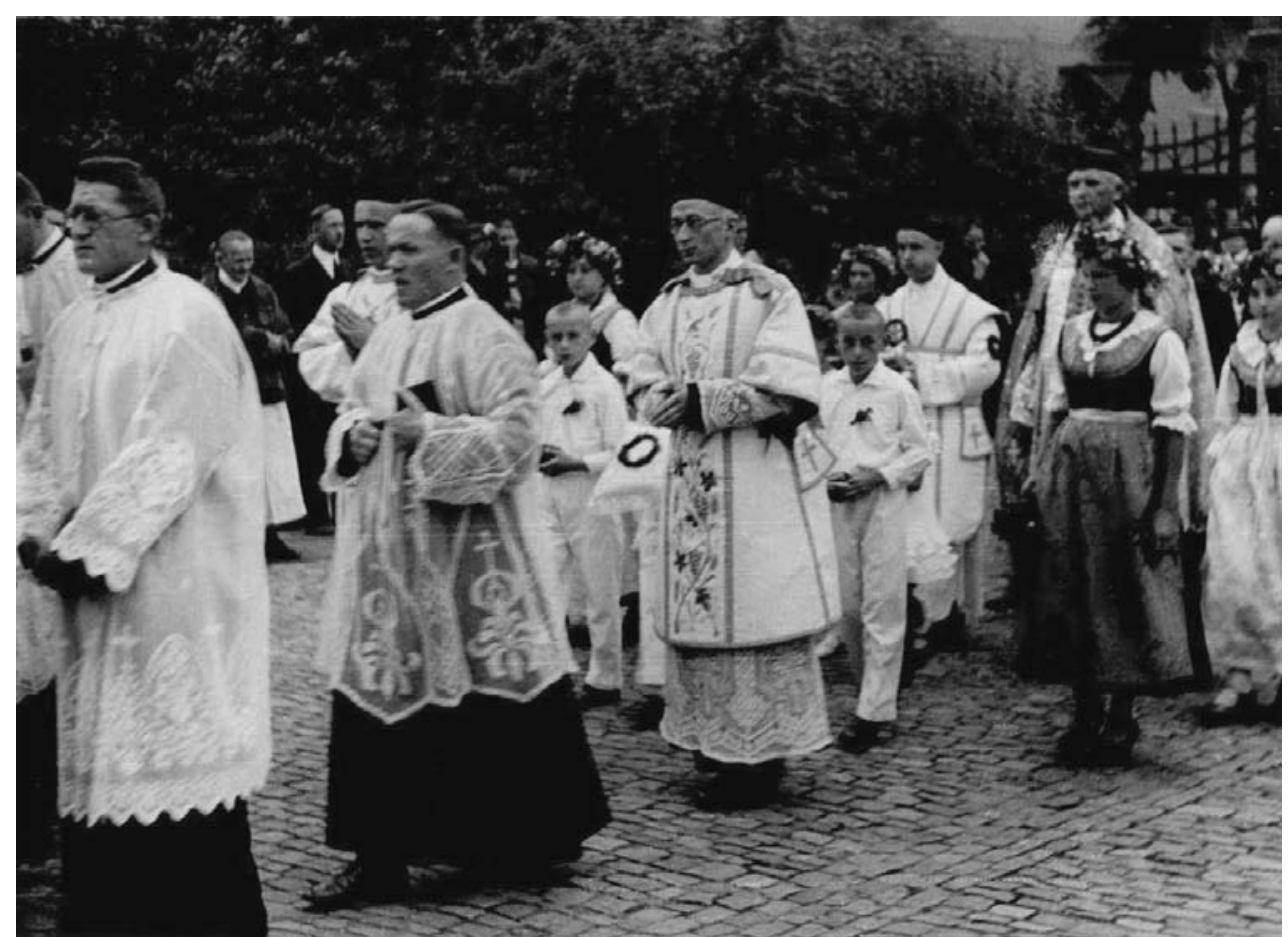

Il. 1. Ks. Ignacy Jeż - prymicja, parafia pw. św. Piotra i Pawła w Katowicach 21.06.1937 r.

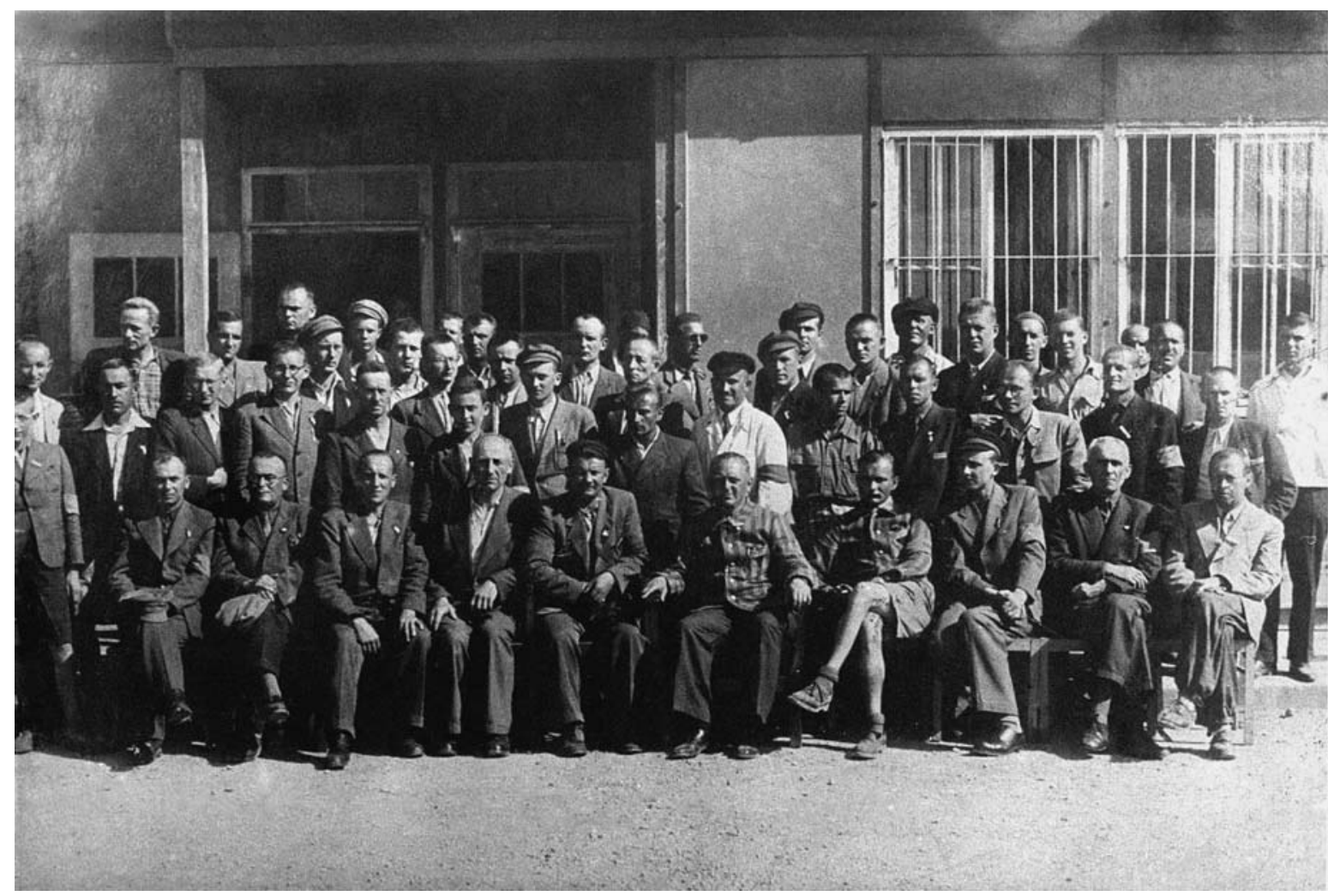

Il. 2. Tuż po uwolnieniu więźniów z obozu w Dachau 1945 r.; ks. Ignacy Jeż w drugim rzędzie trzeci od lewej 


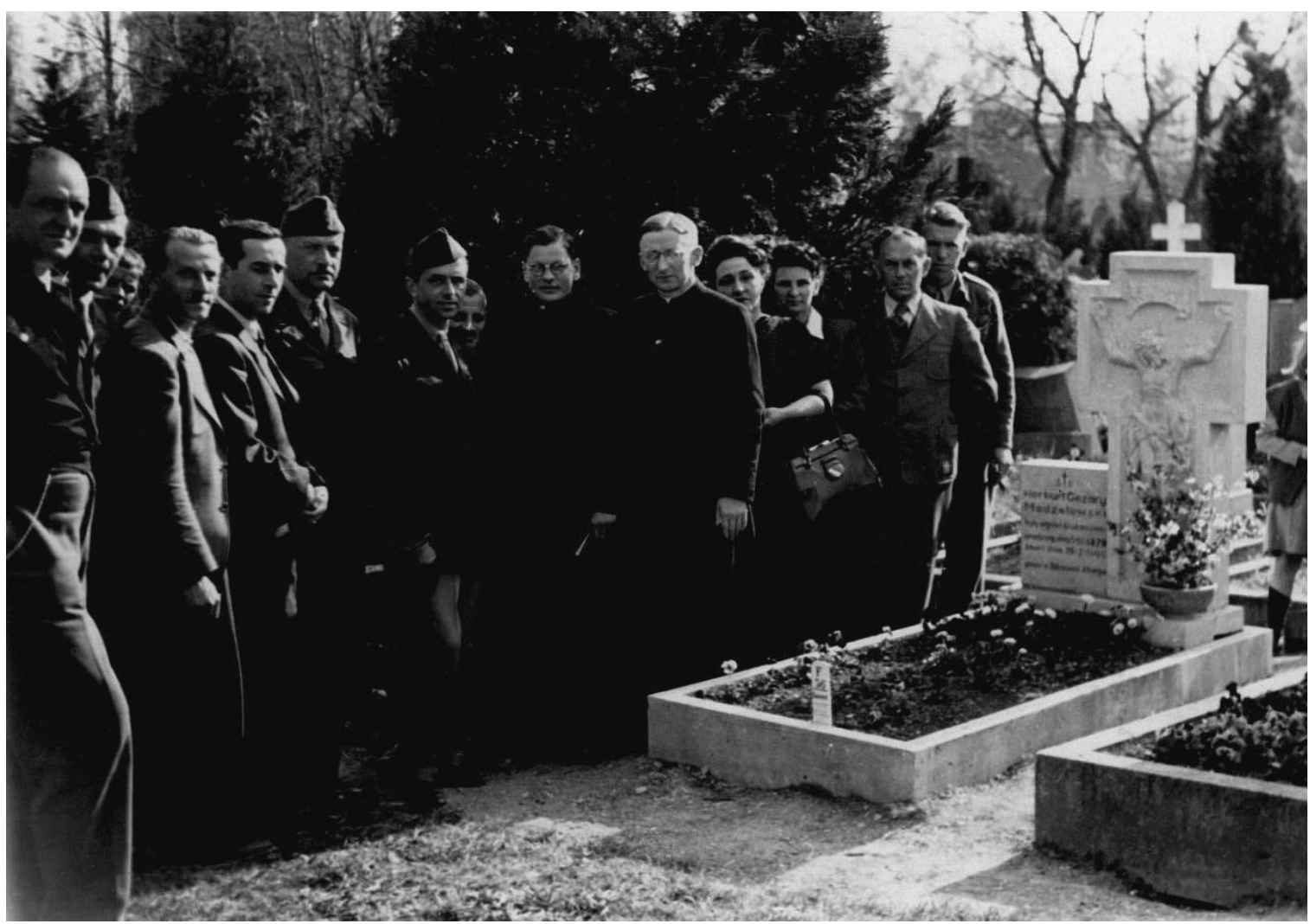

Il. 3. Ks. Ignacy Jeż z aliantami na cmentarzu polskim w Göppingem 1946 r.

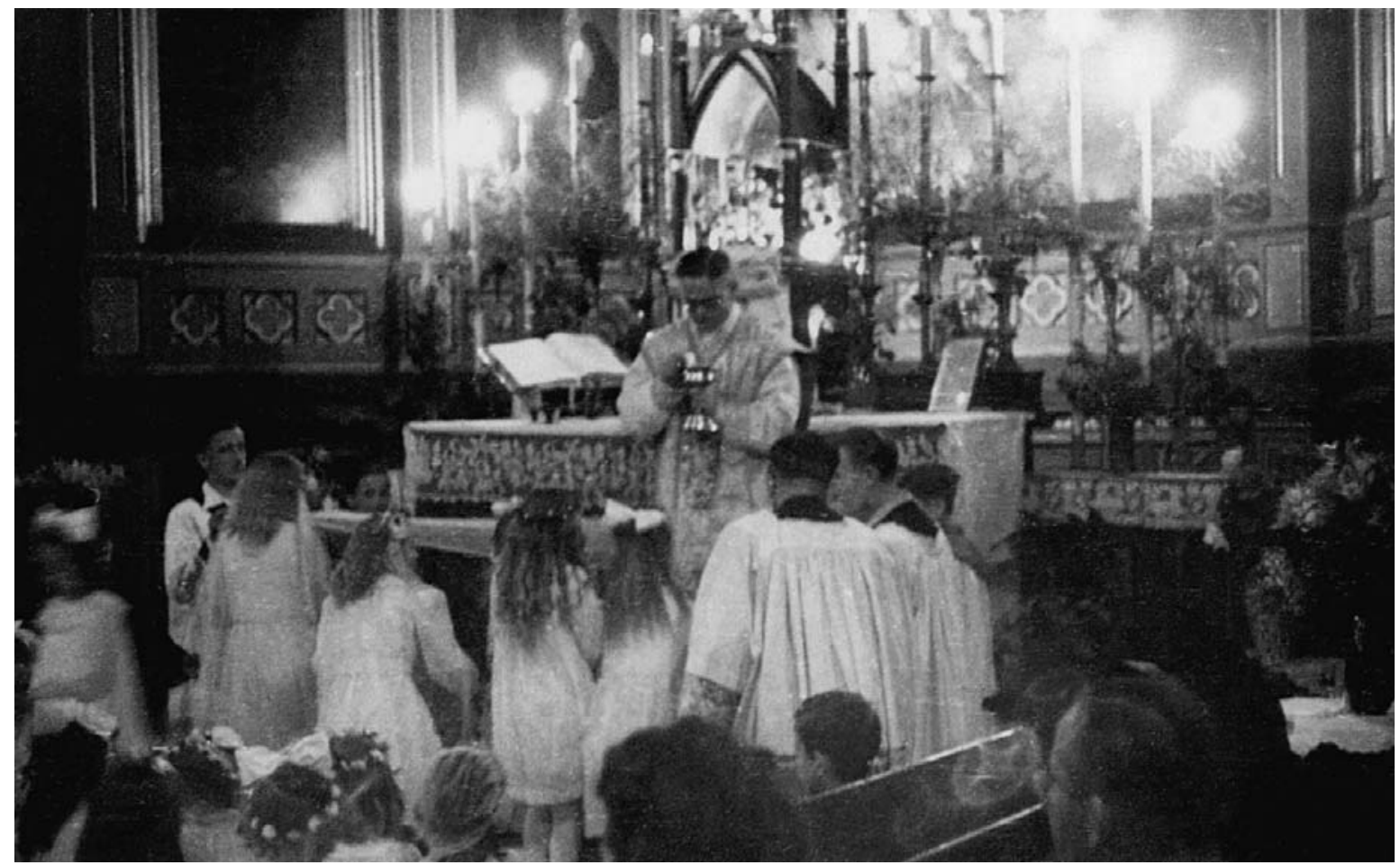

Il. 4. Pierwsza Komunia Św., kościół pw. św. Józefa w Koszalinie 1946 r. 


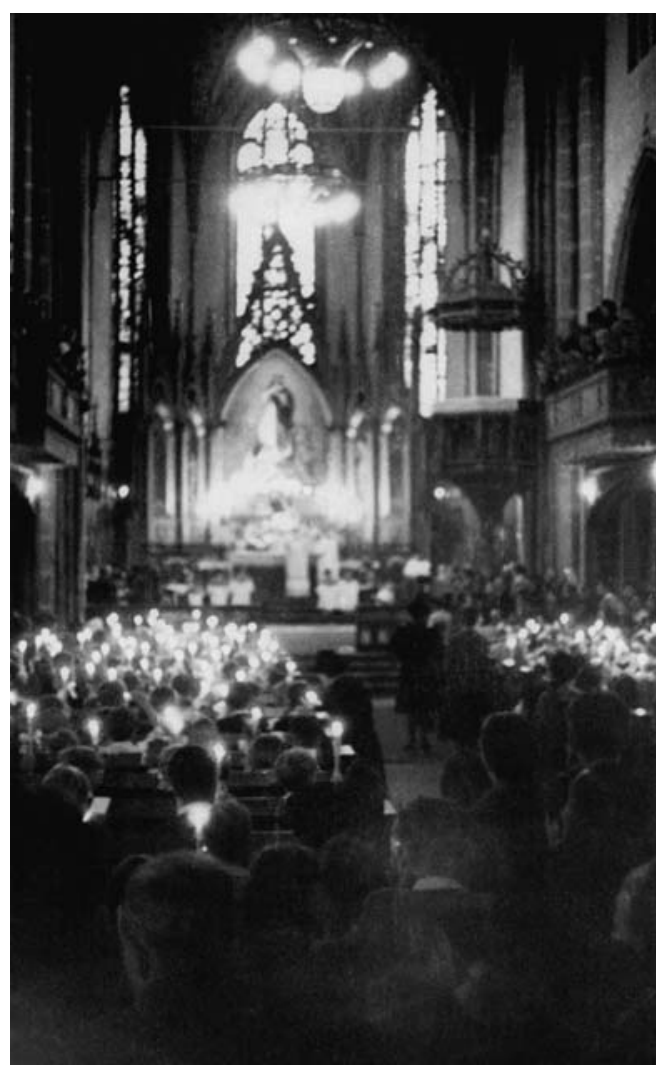

Il. 5. Dzieci z zapalonymi świecami podczas mszy św. w oczekiwaniu na Pierwszą Komunię Św., kościół pw. św. Józefa w Koszalinie 1946 r.

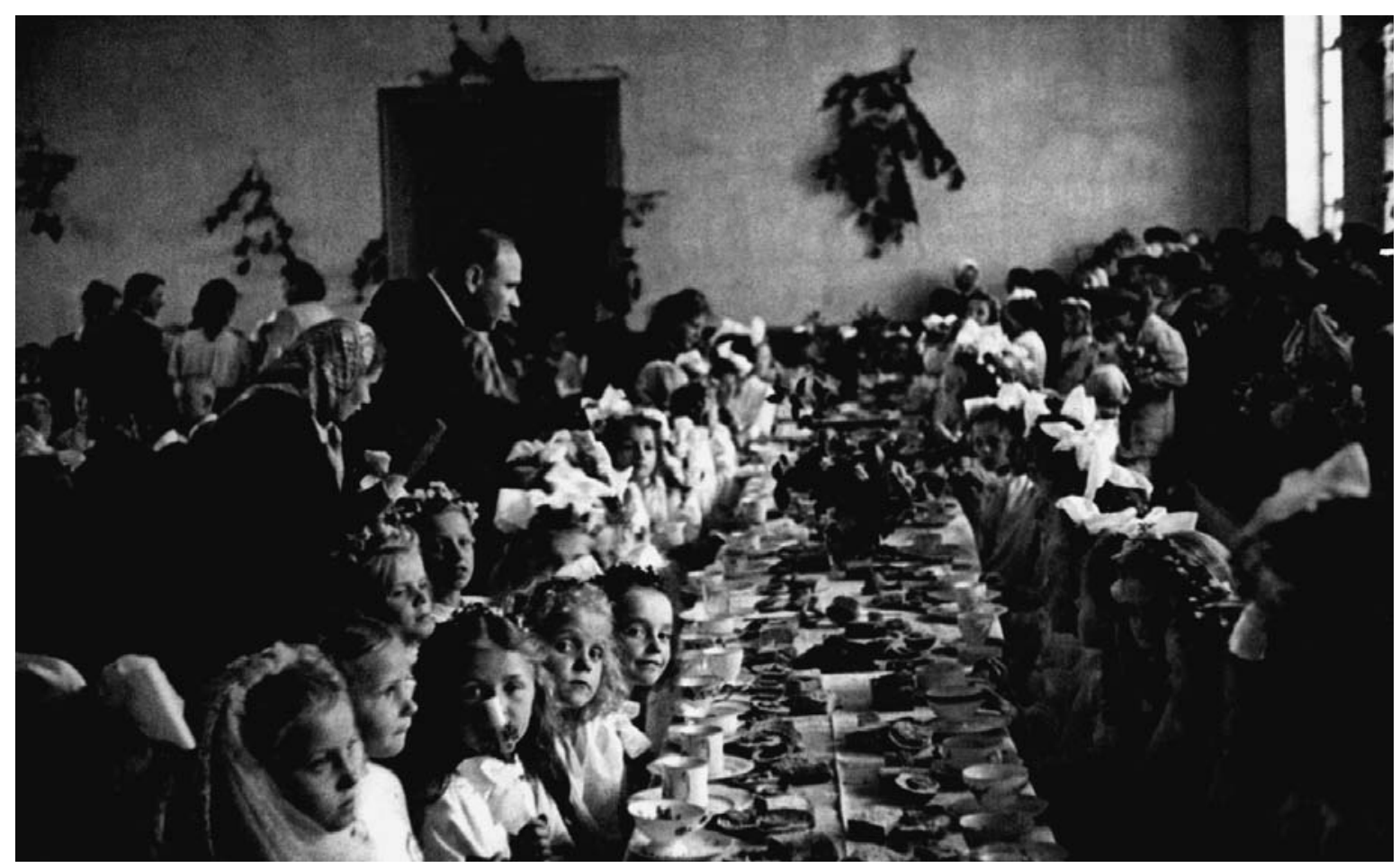

Il. 6. Śniadanie po Pierwszej Komunii Św., Koszalin 1946 r. 


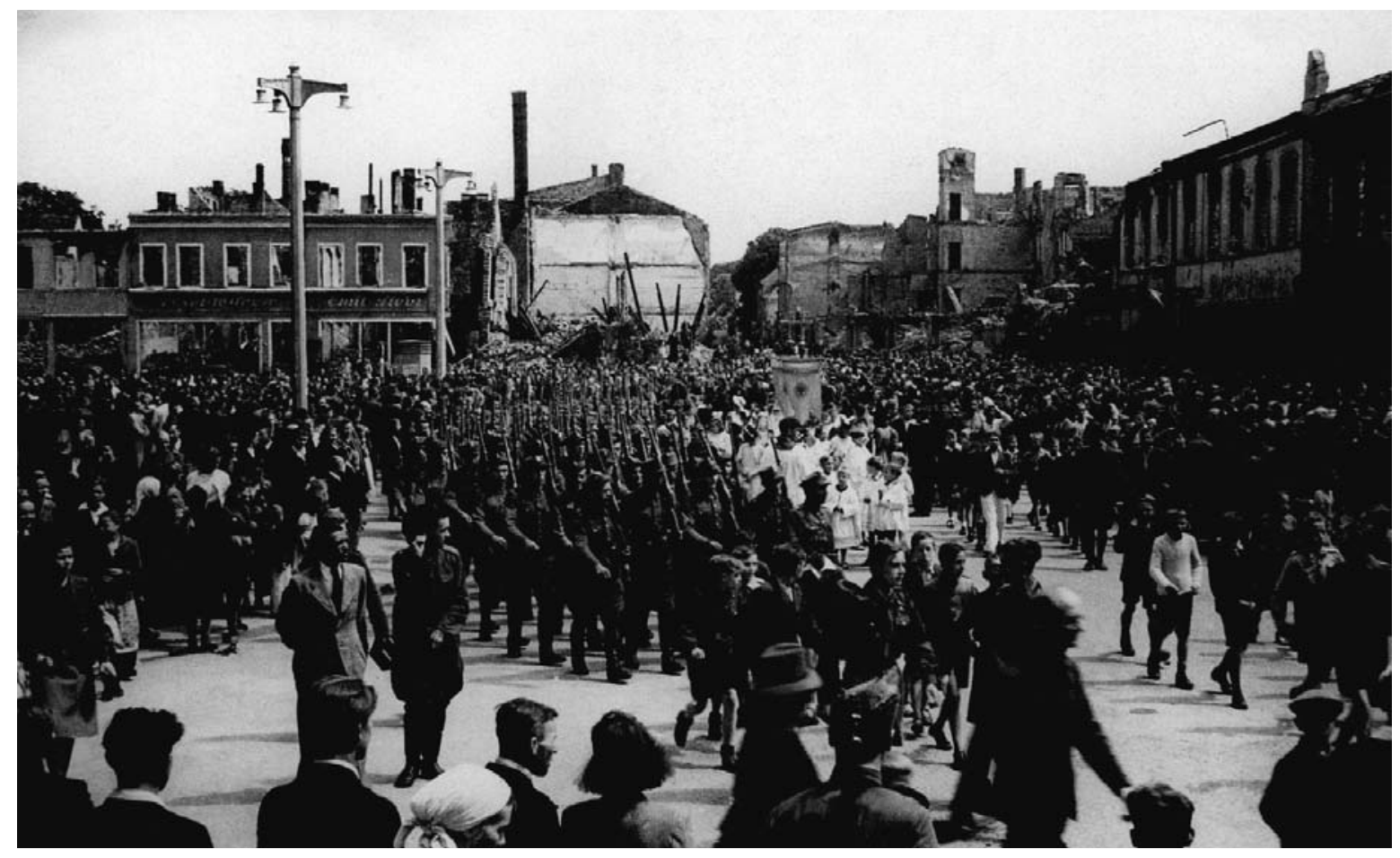

Il. 7. Wojsko na procesji Bożego Ciała w Koszalinie 1946 r.

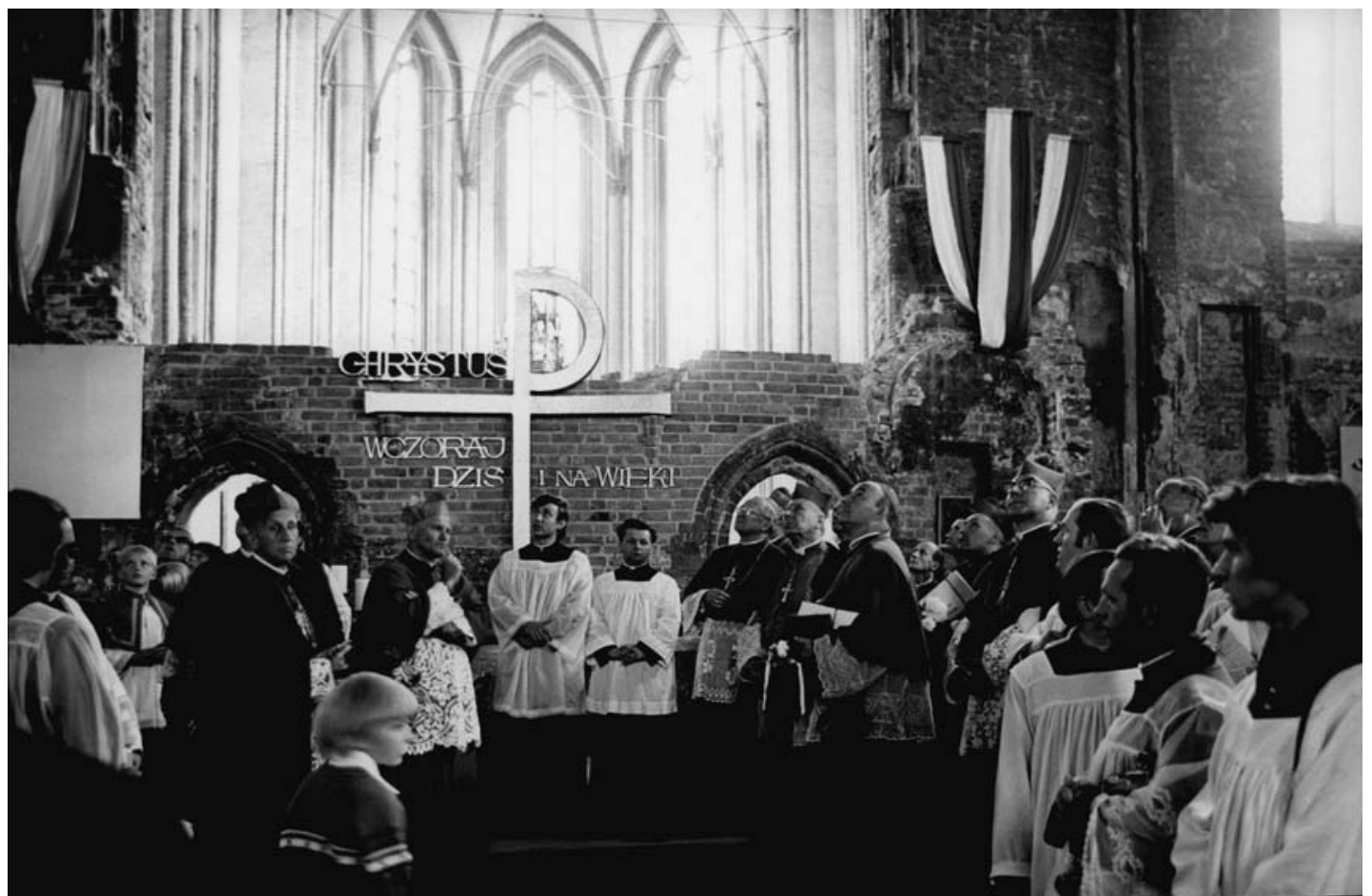

Il. 8. Uroczystości 975-lecia organizacji kościelnej w Polsce, Kołobrzeg 1975 r. 


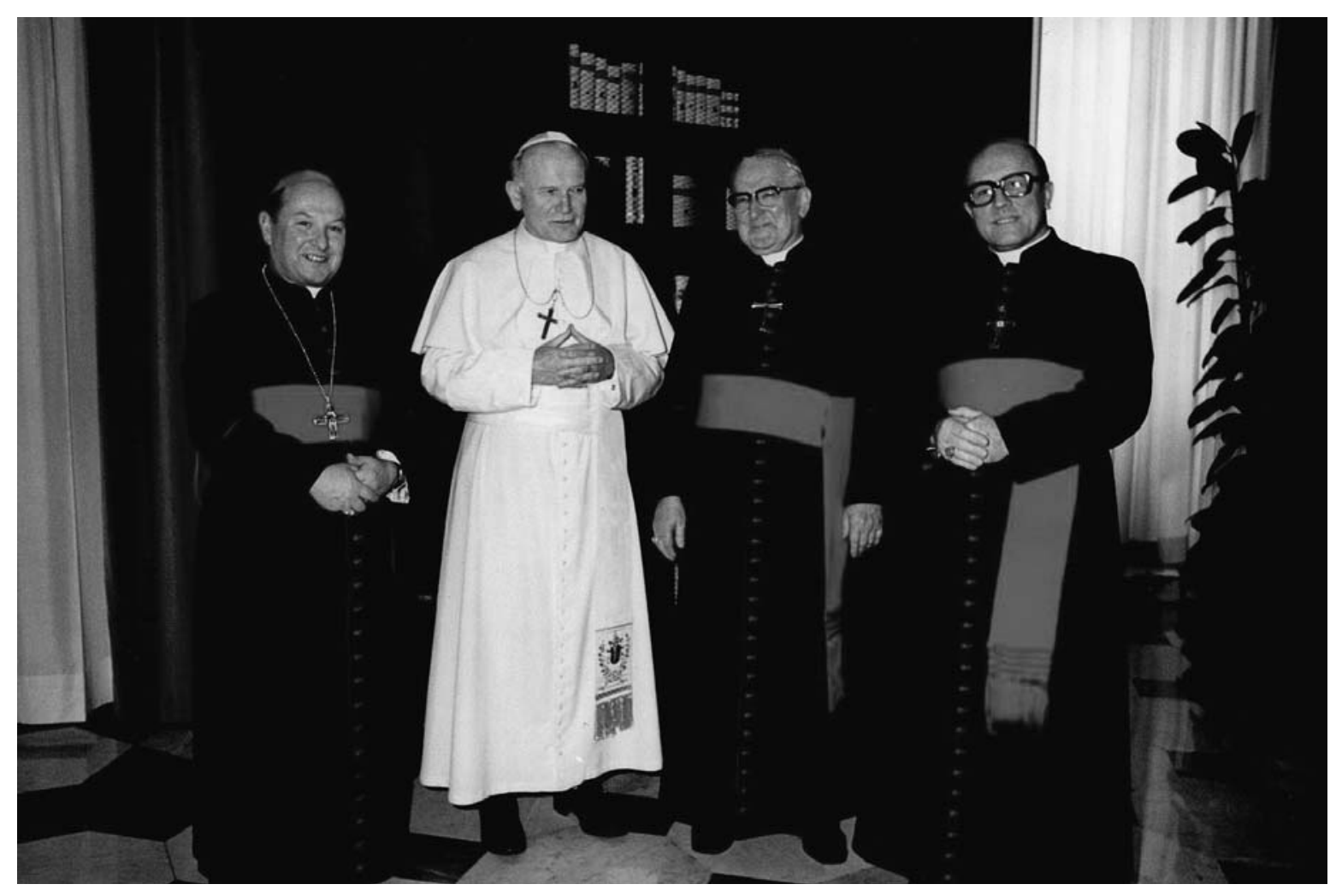

Il. 9. Podziękowanie za pielgrzymkę: od lewej bp Piotr Krupa, papież Jan Paweł II, bp Ignacy Jeż, bp Tadeusz Werno, Rzym 18.11.1991 r.

\section{Stan opracowania i udostępnianie}

Mimo braku zinwentaryzowania zbiorów fotograficznych archiwum diecezjalne w Koszalinie udostępnia swój zasób nieaktowy. Można z niego skorzystać w czytelni akt po wcześniejszym umówieniu się z pracownikiem instytucji. Badacz otrzymuje tymczasowe opisy jednostek i w ten sposób dociera do interesującej go tematyki. Jeżeli zainteresowany kwerendzista wyrazi chęć wykorzystania poszczególnych obiektów, otrzymuje kopię w formie cyfrowej ${ }^{17}$. Do tej pory największym zainteresowaniem cieszą się zbiory dotyczące wydarzeń milenijnych na Pomorzu, pobytów błogosławionego prymasa S. Wyszyńskiego na terenie diecezji oraz pielgrzymki papieskiej. Ze względu na ograniczone możliwości finansowe archiwum nie podjęto jeszcze próby zeskanowania całego zbioru. W przyszłym roku zakończy się cyfryzacja ksiąg metrykalnych. Wykorzystywanie fotografii w publikacjach naukowych wymaga zgody dyrektora archiwum. Dostęp do nich jest bezpłatny, ale kopie cyfrowe, w zależności od formatu, należy opłacić według aktualnego cennika. Poważny problem stanowią fotografie niezidentyfikowane, dołączone do spuścizn biskupów. Opracowując te zdjęci, pracownicy archiwum zwracają się o pomoc do księży emerytów, naocznych świadków wydarzeń. W celu opisu niektórych jednostek bp. I. Jeża i bp. C. Domina poproszono o konsultacje pracowników archiwum w Katowicach. Poniżej przedstawio-

${ }^{17} \mathrm{~W}$ tym celu wykorzystuje się skaner archiwalny lub zleca się tę czynność wyspecjalizowanej instytucji. 
no zbiory ze spuścizny bp. C. Domina, które wchodzą w skład całego opracowanego zespołu ${ }^{18}$, oraz wstępną fazę opracowanych fotografii po bp. I. Jeżu ${ }^{19}$.

\section{Bp Czesław Domin}

dokumentacja fotograficzna - do 1992 r.

1. Dzieciństwo, sygn. 1/1-22

2. Śląskie Seminarium Duchowne, sygn. 2/1-24

3. Góra św. Anny, sygn. 3/1

4. Wikarzy, sygn. 4/1-22

5. Święcenia kapłańskie, sygn. 5/1-20

6. Jejkowice, sygn. $6 / 1-2$

7. 1962 - wakacje, sygn. $7 / 1-26$

8. 1962 - wakacje, sygn. 8/1-21

9. Rybnik, Piekary, sygn. 9/1-6

10. 1963-1965, sygn. 10/1-6

11. Piekary Śląskie, sygn. 11/1-2

12. Katowice $-\mathrm{z}$ mamą, sygn. $12 / 1-12$

13. Piekary, pielgrzymka kobiet, sygn. 13/1-2

14. Wizytacje watykańskie w Chorzowie, parafia pw. Ducha Świętego, sygn. 14/1-12

15. Riedlowie, sygn. 15/1-4

16. Kuzyn ksiądz, sygn. 16/1-4

17. Sygn. $17 / 1-7$

18. Sygn. $18 / 1-2$

19. Sygn. $19 / 1-7$

20. Sygn. $20 / 1-7$

21. Sygn. $21 / 1-2$

22. Sygn. $22 / 1-24$

23. Sygn. $23 / 1-6$

24. Sygn. $24 / 1-8$

25. Sygn. $25 / 1-4$

26. Dzieci komunijne, Katowice, sygn. 26/1-30

27. Wizytacja kanoniczna, parafia Jaworzynka, sygn. 27/1-10

28. Bierzmowanie, sygn. 28/1-18

29. Koronacja obrazu Matki Boskiej Piekarskiej, sygn. 29/1

30. Nowy Targ 4 XI 1967, sygn. 30/1

31. Pielgrzymka księży na Jasną Górę 1967 r., sygn. 31/1

32. Konsekracja JE Ks. Bpa Cz. Domina, Katowice 15.08.1970, sygn. 32/1-6

33. Wizytacja 1970 , sygn. $33 / 1$

34. Trzebnica 16 X 1970, sygn. 34/1-4

35. Paradyż, Episkopat 1971, sygn. 35/1-2

36. Kraków 1971, sygn. 36/1

37. Oświęcim 17.10.1971, sygn. 37/1-12

${ }^{18}$ Dokumentacja aktowa składa się ze 106 jednostek archiwalnych.

${ }^{19}$ Bogata dokumentacja aktowa czeka na specjalistyczną inwentaryzację. 
38. Kraków, maj 1971, sygn. 38/1-9

39. Wizytacja w parafii zakonnej, Czechowice-Dziedzice, 2.05.1971, sygn. 39/1-39

40. Jasna Góra 5.09.1971, sygn. 40/1-5

41. Lubaczów 11.07.1971, sygn. 41/1-6

42. Jarosław 17.07.1971, sygn. 42/1-6

43. 25-lecie kapłaństwa ks. Alojzego Tomeckiego, Roszczyce 1971, sygn. 43/1-2

44. Konferencja Episkopatu 1971, sygn. 44/1-6

45. Pasterka, Chorzów 1971, sygn. 45/1-5

46. Wizytacja kanoniczna, Mokre 29.04.1972, sygn. 46/1-8

47. I rocznica wczesnej komunii św., Czechowice-Dziedzice 28.03.1972, sygn. 47/1-2

48. Święcenia diakonatu, Drogomyśl 1972, sygn. 48/1-6

49. Jasna Góra 7.05.1972, sygn. 49/1-10

50. Wizytacja kanoniczna u sióstr Boromeuszek, Cieszyn 1973, sygn. 50/1-8

51. Wizytacja kanoniczna św. Marii Magdaleny, Cieszyn 28.09.1973, sygn. 51/1-14

52. Wizytacja kanoniczna św. Elżbiety, Cieszyn 14.10.1973, sygn. 52/1-23

53. Wizytacja kanoniczna św. Jerzego, Cieszyn 2.11.1973, sygn. 53/1-18

54. Wizytacja kanoniczna Bonifratrzy, Cieszyn 1973, sygn. 54/1-16

55. 20-lecie kapłaństwa, Czechowice-Dziedzice 1973, sygn. 55/1-4

56. Smardzewie - koronacja obrazu 1873, Jasna Góra 1973, sygn. 56/1-2

57. Wizytacja kanoniczna, Koszutka 17-18.03.1973, sygn. 57/1-3

58. Pielgrzymka do Piekar 1973-1974, sygn. 58/1-2

59. Rzym 25.06.1975, sygn. 59/1-10

60. Rzym, spotkanie z papieżem Pawłem VI 1975, sygn. 60/1-2

61. Wizytacja kanoniczna, Połomia 7.03.1975, sygn. 61/1-3

62. Saulgom/Bolstern 1976, sygn. 62/1-4

63. 25-lecie kapłaństwa, Jasna Góra 1978, sygn. 63/1-4

64. Rzym, bazylika św. Piotra 21 X 1978, sygn. 64/1-5

65. Pielgrzymka niemiecka lipiec 1978, sygn. 65/1

66. Piekary 1979 , sygn. $66 / 1$

67. Warszawa 1980 , sygn. $67 / 1-4$

68. Fatima 1980, sygn. $68 / 1-2$

69. Neoprezbiterzy 1980-1987, Kraków-Katowice, sygn. 69/1-2

70. Prymas Wyszyński, jego ostatnia droga 28-31.05.1981, zdjęcia wcześniejsze, sygn. 70

71. Warszawa z delegacją episkopatu USA 1981, sygn. 71/1-2

72. Rekolekcje 1982, sygn. 72/1

73. Londyn 1982, sygn. 73/1

74. Częstochowa 1982, sygn. 74/1-2

75. Neoprezbiterzy 1975-1982, Kraków-Katowice, sygn. 75/1

76. Rekolekcje, Góra św. Anny 1983, sygn. 76/1-2

77. 1984 , sygn. $77 / 1$

78. Bad Kissinger 1987, sygn. 78/1-5

79. Synod Biskupów Europy, Rzym 4.12.1991, sygn. 79/1

80. Kaplica kurialna, Katowice 1992, sygn. 80/1-2

81. Marzec 1981, sygn. 81/1-10 
82. 1992, sygn. 82/1-14

83. Chicago 1986, sygn. 83/1-44

84. Album, sygn. 84/1-38

85. Kronika Dekanatu Katowice 1923-1953, sygn. 85

86. Wizytacja duszpasterska, Boguszowice 1980, sygn. 86/1-25

87. Spotkanie kolędowe, Piekary Śląskie 1981, album, sygn. 87/1-25

88. Wizytacja kanoniczna, Poręba 1985, album, sygn. 88/1-22

89. Wizytacja kanoniczna, Knurów 1986, album, sygn. 89/1-30

90. Pobyt w Chicago 1986, album, sygn. 90/1-31

91. Zdjęcia, wycinki prasowe, album, sygn. $91 / 1-22$

92. Segregator ze zdjęciami z lat 1981-1987, sygn. 92

93. Chicago 1986, sygn. 93

94. Segregator ze zdjęciami z lat 1988-1992, sygn. 94

95. Zdjęcia portretowe ks. bp. Czesława Domina, sygn. 95/1-10

\section{Dokumentacja fotograficzna - od 1992 r.}

96. Ingres do katedry koszalińskiej 1992, sygn. 96/1-5

97. Ingres do katedry koszalińskiej 1992, sygn. 97/1-10

98. Ingres do katedry koszalińskiej 1992, sygn. 98/1-11

99. Ingres do katedry koszalińskiej 1992, sygn. 99/1-5

100. Ingres do katedry koszalińskiej 1992, sygn. 100/1-8

101. Ingres do katedry koszalińskiej 1992, sygn. 101/1-11

102. Ingres do katedry koszalińskiej 1992, sygn. 102/1-10

103. Ingres do katedry koszalińskiej 1992, sygn. 103/1-10

104. Ingres do katedry koszalińskiej 1992, sygn. 104/1-10

105. Ingres do katedry koszalińskiej 1992, sygn. 105/1-9

106. Ingres do katedry koszalińskiej 1992, sygn. 106/1-9

107. Ingres do katedry koszalińskiej 1992, sygn. 107/1-10

108. Ingres do katedry koszalińskiej 1992, sygn. 108/1-10

109. Ingres do katedry koszalińskiej 1992, sygn. 109/1-7

110. Ingres do konkatedry kołobrzeskiej 05.04.1992, sygn. 110/1-10

111. (po ingresie) Kołobrzeg, sygn. 111/1-4

112. Wizytacja - Sławno 21-23.03.1992, sygn. 112/1

113. Spotkanie z rodziną wielodzietną, Słupsk św. Jacka, Schronisko Br. Alberta, sygn. 113/1-7

114. Spotkanie z siostrami szensztackimi 1993, sygn. 114/1

115. Spotkanie z władzami Koszalina, sygn. 115/1-14

116. Słupsk 1993, sygn. 116/1-2

117. Spotkanie z władzami Koszalina, sygn. 117/1-4

118. Słupsk 6 XI 1994, sygn. 118/1

119. WSD Koszalin, sygn. 119/1-3

120. WSD Koszalin, sygn. 120/1-3

121. Słupsk, św. Maksymiliana, sygn. 121/1

122. Odpust w Skrzatuszu, sygn. 122/1-14

123. Kołobrzeg 1994-1995, sygn. 123/1-3 
124. Siostra Josefa Tobre - Koszalin 1995, sygn. 124/1-8

125. Podczele, Kołobrzeg, sygn. 125/1-13

126. Tablica informacyjna Kurii Koszalińskiej, sygn. 126/1

127. Podczele, Kołobrzeg, Aniołów Stróżów i ul. Arciszewskiego, sygn. 127/1-22

128. Piła, sygn. 128/1-36

129. Rozpoczęcie pielgrzymki Skrzatusz-Częstochowa 1995, sygn. 129/1-24

130. Skrzatusz 1992, sygn. 130/1-36

131. Skrzatusz - filie 1992, sygn. 131/1-25

132. Liskowo - gospodarstwo (koziarnia), sygn. 132/1-25

133. Jezierzyce, sygn. $133 / 1-16$

134. Wizytacja, bierzmowanie, sygn. 134/1-32

135. Kobylnica NSP Jezusa 1994, sygn. 135/1-12

136. Słupsk - Cech Rzemiosł Różnych 1994, sygn. 136/1-25

137. Niepokalanów, zjazd proboszczów kościołów i kaplic pw. św. Maksymiliana Kolbe 6.04.1994, sygn. 137/1

138. Góra Chełmska, sygn. 138/1-15

139. Dom Samotnej Matki, Boże Narodzenie 1992, sygn. 139/1

140. Wyższa Szkoła Oficerska 1992, sygn. 140/1

141. 1994, sygn. 141/1-2

142. VIII 1995, sygn. 142/1-18

143. Kalisz 1995, sygn. 143/1-2

144. Wizytacja kanoniczna, Sławno 21-23.03.1992, sygn. 144/1-20

145. Uzdrowisko Połczyn-Zdrój 1993, sygn. 145/1-20

146.Wizytacja duszpasterska w szkole podstawowej w Jezierzycach 1994, album, sygn. 146/1-15

147. 08.1995, sygn. $147 / 1-71$

148. Pogrzeb bp. Czesława Domina, sygn. 148/1-4

149. Siemianowice 1995, sygn. 149/1

150. Rusinowice 1994, sygn. 150/1

151. 25-lecie sakry biskupiej ks. abp. Szczepana Wesołego, Katowice 30.05.1994, sygn. $151 / 1$

152. Piekary 05.1992 , sygn. $152 / 1-2$

153. Kurs wstępny WSD Koszalin, wrzesień 1994 (rocznik ks. dr. Tomasza Tomaszewskiego), sygn. 153/1

154. Segregator - zdjęcia z lat 1993-1994, sygn. 154

155. Księża wyświęceni w roku 1986 (rocznik ks. bp. Krzysztofa Zadarko), sygn. $155 / 1$

156. Kołobrzeg, przed konkatedrą, sygn. 156/1

157. Kondukt pogrzebowy ks. bp. Cz. Domina, sygn. 157/1

Razem 2469 fotografii 


\section{Dokumentacja fotograficzna w zespole bpa Ignacego Jeża}

1. Pielgrzymka Narodowa do Budapesztu na uroczystości jubileuszowe ku czci św. Emeryka od 17 do 25 sierpnia 1930 - 18 zdjęć

2. Album ze zdjęciami z Rzymu 1927 rok - 109 zdjęć

3. Pielgrzymka do Ziemi Świętej odbyta w czasie od 26 marca do 2 maja 1930 roku z inicjatywy ks. dziekana Smoleńskiego - 61 zdjęć

4. „Jacek” w swojej obrazkowej historii 1946-1956 - 63 zdjęcia

5. W dowód wdzięczności za całoroczną naukę religii... - Katowice 23 VI 1952 69 zdjęć

6. Pogląd na dzieje dekanatu katowickiego 1923-1953 - 160 zdjęć

7. Album T. I. 1937-1972 - bp Jeż - 109 zdjęć

8. Album T. II 1972-1985 - bp Jeż - 143 zdjęcia

9. Album T. III 1986-1998 - bp Jeż - 128 zdjęć

10. Pogląd na dzieje dekanatu mysłowickiego 1868-1953 - 134 zdjęcia

11. Pogląd na dzieje dekanatu piekarskiego $1954-175$ zdjęć

12. Zacnemu ks. Rektorowi i umiłowanemu wychowawcy z okazji imienin alumni i kurs wstępny w Tarnowskich Górach 1955/1956 - 65 zdjęć

13. Rok 1958, rejs jeziorami - 28 zdjęć

14. „Gwiazdka” w Niższym Seminarium Duchownym im. św. Jacka w Katowicach, 20 XII 1959 - 14 zdjęć

15. J.E. Księdzu Biskupowi Ignacemu Jeżowi na pamiątkę miłych odwiedzin, parafia Dębno Lubuskie 1961 - 59 zdjęć

16. W dowód uległości, wdzięczności i przywiązania do zwierzchników Kościoła Chrystusowego ofiaruje młodzież przy parafii pw. Chrystusa Króla, Gorzów Wlkp. 1961 - 57 zdjęć

17. W jubileuszowym hołdzie na pamiątkę pobytu w Pile, 19 czerwca 1962 28 zdjęć

18. Biskupowi Ignacemu Jeżowi - Ministranci parafii pw. św. Rodziny w Pile, 8 stycznia 1962 - 33 zdjęcia

19. Młodzież parafii Półczno J. Eks. Ks. Biskupowi Ignacemu Jeżowi w dzień poświęcenia organów, 15 VII 1962 - 45 zdjęć

20. Pamiątka I Komunii św. dzieci głuchych - 16 lipca 1963, Gorzów Wlkp., parafia Chrystusa Króla - 56 zdjęć

21. Album kościoła NP NMP, parafii św. Józefa w Koszalinie przed i po malowaniu w 1963 roku - 16 zdjęć

22. Pamiątka wizytacji kanonicznej dekanatu człuchowskiego przez J.E. ks. bp. Ignacego Jeża, 3 V - 3 VI 1963 - 81 zdjęć

23. Sacrum Poloniae Millenium, Szczecin, Gorzów Wielkopolski 1966 - 78 zdjęć

24. Z życia ośrodka duszpasterskiego w Charzynie w parafii Kołobrzeg, poświęcenie wystroju wnętrza, 1968 - 55 zdjęć

25. Dokumentacja konserwatorska, ołtarz XVIII w. z kościoła filialnego w Boleszewie, 1970 - 80 zdjęć

26. Kalisz 28-29 IV 1970 - 16 zdjęć

27. Wizytacja w parafii pw. św. Józefa w Koszalinie, bp Ignacy Jeż, 23.04 26.04.1971 - 97 zdjęć

28. Poświęcenie sztandaru Solidarności, parafia pw. św. Maksymiliana w Słupsku - 22 zdjęcia 
29. Arcypasterzowi - Ojcu Diecezji wierny i wdzięczny Szczecinek, 7 XI 1974 25 zdjęć

30. Album śpiewajmy Panu! Słupsk, nr 1 - 1974-1982 - 82 zdjęcia

31. Album - Koszalin, pielgrzymki, 1974-1976 - 166 zdjęć

32. Uroczystości 850-lecia Chrztu Pomorza, Szczecin 1974 - 34 zdjęcia

33. Album pielgrzymki, oazy, grupy - Słupsk 1975-1979 - 92 zdjęcia

34. Album - różne, Szczecinek 1974, Koszalin 1975 - 206 zdjęć

35. Dokumentacja konserwatorska Krucyfiks, Kołobrzeg 1976 - 21 zdjęć

36. Maryjny Ingres do Archidiecezji Poznańskiej - Ostrów Wlkp. 7 XI 1976 13 zdjęć

37. Album młodzieży studiującej i pracującej, Słupsk 1976-1978 - 57 zdjęć

38. Album maturzyści Słupsk NMP od 1976 nr 1, 1976-1982 - 110 zdjęć

39. Album, pielgrzymi, Słupsk lata 1979-1981 - 158 zdjęć

40. Album parafia pw. św. Jacka, Słupsk 1979-1984 - 212 zdjęć

41. Młodzież akademicka pracująca nr 3, Słupsk 1980-1984 - 122 zdjęcia

42. Album Solidarność polska - 1980-1985 - 45 zdjęć

43. Album lata 1981-1984, m.in bp Werno - 74 zdjęcia

44. Pielgrzymka Pomorska Piesza od 1981 do 1982 - 127 zdjęć

45. Diecezja Szczecińsko-Kamieńska 1982 - 12 zdjęć

46. Jezierzyce 1983 , w prezencie na imieniny proboszcza - 46 zdjęć

47. Rok 1985, Słupsk - 91 zdjęć

48. Kronika budowy WSD w Koszalinie, 1982-1986 - 90 zdjęć

49. Jubileusz 25-lecia sakry biskupiej ks. bp. Ignacego Jeża, 1960-1985 - 15 zdjęć

50. Lotyń, wizytacja parafii 21 września 1989, bp Ignacy Jeż -8 zdjęć

51. Pielgrzymka polskich biskupów do Monachium, Dachau, Freising, Gars i Altötting 20-23.06.1989 - 101 zdjęć

52. Album - pomoc z Niemiec dla Polski, bp Jeż, 1992 - 27 zdjęć

53. Bazylika - Kołobrzeg, 1996 - 15 zdjęć

54. Tryptyk w kościele Mariackim w Koszalinie, dokumentacja konserwatorska 67 zdjęć

55. Święcenia biskupie - bp Jeż - 27 zdjęć

56. Pamiątka z wizytacji ks. Ignacego Jeża, biskupa koszalińsko-kołobrzeskiego w Zakładzie Poprawczym i Schronisku Młodzieżowym w Koszalinie 15 zdjęć

57. Jego Ekscelencję Najprzewielebniejszego X. Bpa Ignacego Jeża... - Katowice, Garnizonowy Kościół św. Kazimierza w II roku watykańskiego Soboru Powszechnego - 38 zdjęć

58. Album nr 4, bez opisu, zdjęcia z niemieckimi podpisami - 126 zdjęć

59. Album nr 6, bez opisu - 50 zdjęć

60. Srebrny Jubileusz bp. Jeża, Słupsk -37 zdjęć

61. Anuntio Vobis Gaudium Magnum - 21 zdjęć

62. Album nr 20, bez opisu - 12 zdjęć

63. Album nr 30, bez opisu, uroczystości milenijne - 66 zdjęć

64. Album nr 31, bez opisu, bp Jeż - 83 zdjęcia

65. Album nr 51, zdjęcia luzem, bez opisu - 74 zdjęcia

Razem 5487 fotografii 


\section{Zakończenie}

Powyższe, wstępne opracowanie zbiorów fotograficznych zdeponowanych w Archiwum Diecezji Koszalińsko-Kołobrzeskiej z całą pewnością przedstawia jedynie zarys problematyki dotyczącej przechowywanych w nim zdjęć. Dopiero podjęcie specjalistycznej i czasochłonnej inwentaryzacji odsłoni całe bogactwo archiwalnych zasobów. Korzystanie z doświadczeń archiwów kościelnych i państwowych, o dłuższym stażu funkcjonowania, pozwoli pracownikom archiwum diecezjalnego w Koszalinie na fachowe opracowanie miejscowych zbiorów fotograficznych. Bezsprzecznie punktem odniesienia będą rady metodyków archiwistyki, jak i ostatnie zarządzenie Naczelnego Dyrektora Archiwów Państwowych ${ }^{20}$.

\section{REFERENCES / BIBLIOGRAFIA}

\section{Źródla}

Archiwum Diecezji Koszalińsko-Kołobrzeskiej, Prywatne Archiwum biskupa Ignacego Jeża, Teczka „Podział”.

Archiwum Kurii Biskupiej, Teczka personalna ks. Bernarda Mielcarzewicza.

Zarządzenie nr 34 z dnia 9 września 2019 r., Dziennik Urzędowy Naczelnego Dyrektora Archiwów Państwowych.

\section{Opracowania}

Bończa-Bystrzycki Lech, Dzieje Kościoła katolickiego na Pomorzu Zachodnim w granicach diecezji koszalińsko-kołobrzeskiej (X-XX/XXI wiek), Koszalin 2012.

Bończa-Bystrzycki Lech, Zarys dziejów Kościoła katolickiego na Pomorzu Zachodnim w granicach diecezji koszalińsko-kołobrzeskiej, w: Schematyzm Diecezji Koszalińsko-Kołobrzeskiej, Koszalin 1998, s. 69-87.

Ceynowa Tadeusz, Archiwum Diecezji Koszalińsko-Kołobrzeskiej, w: 40-lecie Diecezji Koszalińsko-Kolobrzeskiej 1972-2012, red. T. Ceynowa, Radom 2012, s. 135-147.

Ceynowa Tadeusz, Archiwum Diecezji Koszalińsko-Kołobrzeskiej - powstanie i funkcjonowanie, w: Przeszłość Kościoła w archiwach Pomorza Zachodniego, red. T. Ceynowa, Radom 2014, s. 133-144.

Ceynowa Tadeusz, Archiwum Diecezji Koszalińsko-Kołobrzeskiej i jego zasób, w: Archiwa ziem zachodnich i pótnocnych Polski (1945-2005). Tradycja i wspótczesne wyzwania, red. K. Kozłowski, Szczecin-Warszawa 2007, s. 187-193.

Ceynowa Tadeusz, Domin Czesław, w: Stownik polskich teologów katolickich 1994-2003, t. 9, red. J. Mandziuk, Warszawa 2006, s. 158-159.

Ceynowa Tadeusz, Duplikaty w Archiwum Diecezji Koszalińsko-Kołobrzeskiej, w: Nova et vetera. Aktualne problemy archiwów diecezjalnych $w$ Polsce, red. W. Żurek, Lublin 2016, s. 87-99.

Ceynowa Tadeusz, Jeż Ignacy, w: Stownik polskich teologów katolickich 2004-2013, t. 10, Warszawa 2019, red. T. Błaszczyk, s. 453-457.

${ }^{20}$ Zarządzenie $n r 34$ z dnia 9 września 2019 r., „Dziennik Urzędowy Naczelnego Dyrektora Archiwów Państwowych". 
Ceynowa Tadeusz, Katolickie księgi metrykalne diecezji koszalińsko-kołobrzeskiej, „Archiwa, Biblioteki i Muzea Kościelne”, 113 (2020) s. 49-78.

Ceynowa Tadeusz, Koszalińsko-kołobrzeska diecezja, w: Encyklopedia katolicka, t. 9, red. A. Szostek, Lublin 2002, kol. 976-978.

Ceynowa Tadeusz, Ksiegi metrykalne parafii rzymskokatolickiej w Grzymałowie przechowywane w Archiwum Diecezji Koszalińsko-Kołobrzeskiej, „Archiwa, Biblioteki i Muzea Kościelne", 112 (2019) s. 93-111.

Dullak Kazimierz, Podstawy prawno-organizacyjne Diecezji Koszalińsko-Kołobrzeskiej, Koszalin 1996.

Inwentarz archiwalny. Materiaty archiwalne przekazane przez Diecezję Gorzowska nowo erygowanej Diecezji Koszalińsko-Kołobrzeskiej z lat 1945-1972, red. T. Ceynowa, Radom 2014.

Narodziny diecezji szczecińsko-kamieńskiej i koszalińsko-kołobrzeskiej (1945-1975), wstęp, wybór i oprac. K. Kozłowski, Szczecin 2007.

Ks. Romuald Kunicki (1934-2017), oprac. T. Ceynowa, „Koszalińsko-Kołobrzeskie Wiadomości Diecezjalne", 45 (2017) nr 2, s. 137-138.

Ks. Stanisław Wojnar (1930-2017), oprac. T. Ceynowa, „Koszalińsko-Kołobrzeskie Wiadomości Diecezjalne", 45 (2017) nr 2, s. 145-146.

Leszczyński Mariusz, Księża diecezjalni ekspatrianci archidiecezji lwowskiej obrządku łacińskiego. Słownik biograficzny, Warszawa 2020.

Marciniak Rafał, Borzyszkowski Jan Sylwester, w: Encyklopedia Solidarności, t. 3: Opozycja w PRL 1976-1989, Warszawa 2019, s. 70.

\title{
A COLLECTION OF PHOTOGRAPHS IN THE ARCHIVES OF THE KOSZALIN-KOLOBRZEG DIOCESE
}

\begin{abstract}
After border agreements being signed between Poland and German Federal Republic in 1970, pope Paul VI established a permanent Church administration in Western Pomerania and Ziemia Lubuska. On that time there was establisted Koszalin-Kolobrzeg (Kołobrzeg) diocese. Koszalin-Kolobrzeg (Kołobrzeg) diocese archive was erected thanks to the third diocesan bishop in year 2003. It is manager according to an approved status and an internal statute. To the archive there are passed files from the bishop curia, parishes, institutions and private persons. Its current content consists of file and non-file documents photographs. Nowadays it makes 18,200 artifacts. Photographis files are not yet processed according to current archive standards. Up to now there had been made some handy lists and there were made some attempts to identify some people and events visible on those photos. Alhhough the not-yet-processed files some single photographs are available for the needs of local exhibitions or scholar works.
\end{abstract}

Keywords: Koszalin-Kolobrzeg (Kołobrzeg) diocese archive; photographs; bishop Czesław Domin; bishop Ignacy Jeż 
